\title{
CORRECTION
}

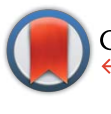

Cite this: J. Mater. Chem. A, 2015, 3, 6685

DOI: $10.1039 / \mathrm{cta}$ ta90046h

www.rsc.org/MaterialsA
View Article Online

View Journal | View Issue

\section{Correction: High-efficiency solid-state polymer electrolyte dye-sensitized solar cells with a bi- functional porous layer}

\author{
Woohyung Cho, Young Rae Kim, Donghoon Song, Hyung Woo Choi \\ and Yong Soo Kang* \\ Correction for 'High-efficiency solid-state polymer electrolyte dye-sensitized solar cells with a bi- \\ functional porous layer' by Woohyung Cho et al., J. Mater. Chem. A, 2014, 2, 17746-17750.
}

The following Acknowledgements section should have appeared after the Conclusion section of the above manuscript:

This work was supported by the National Research Foundation of Korea (NRF) grant funded by the Korea government (MSIP) for the Center for Next Generation Dye-sensitized Solar Cells (no. 2008-0061903) and by the Korea Center for Artificial Photosynthesis (KCAP) (no. 2009-0093883).

The Royal Society of Chemistry apologises for these errors and any consequent inconvenience to authors and readers. 